\begin{tabular}{|l|l|l|}
\hline \multicolumn{2}{|c|}{ PublisherInfo } \\
\hline \hline PublisherName & $:$ & BioMed Central \\
\hline \hline PublisherLocation & $:$ & London \\
\hline \hline PublisherImprintName & $:$ & BioMed Central \\
\hline \hline
\end{tabular}

\title{
Tracking down pathways and molecular interactions
}

\begin{tabular}{|l|l|l||}
\hline \multicolumn{2}{|c|}{ ArticleInfo } \\
\hline \hline ArticleID & $:$ & 4297 \\
\hline \hline ArticleDOI & $:$ & $10.1186 /$ gb-2001-3-1-reports2004 \\
\hline \hline ArticleCitationID & $:$ & reports2004 \\
\hline \hline ArticleSequenceNumber & $:$ & 29 \\
\hline \hline ArticleCategory & $:$ & Web report \\
\hline \hline ArticleFirstPage & $:$ & 1 \\
\hline \hline ArticleLastPage & $:$ & 3 \\
\hline \hline & & RegistrationDate : 2001-11-19 \\
ArticleHistory & $:$ & Received \\
\hline ArticleCopyright & $:$ & BioMed Central Ltd2001-11-19 \\
\hline \hline ArticleGrants & $:$ & \\
\hline \hline ArticleContext & $:$ & 130593311 \\
\hline \hline
\end{tabular}




\section{Eliezer Kopf}

\section{Abstract}

The KEGG project, initiated by the Japanese Human Genome Program in 1995, aims to computerize knowledge on molecular interactions among genes and proteins, metabolic pathways, regulatory pathways and molecular assemblies

\section{Content}

The KEGG project, initiated by the Japanese Human Genome Program in 1995, aims to computerize knowledge on molecular interactions among genes and proteins, metabolic pathways, regulatory pathways and molecular assemblies. The data are presented in graphical diagrams, HTML tables, hierarchical text or Java graphics. The pathway map, for example, covers all known metabolic pathways and some gene regulatory pathways. Each enzyme represented in the diagram is given its standard EC number, which is a useful tag to explore for more information, such as gene data, homologous genes and additional pathways in which the protein is involved. The site contains and maintains genome data such as genome maps and sequences, not only from humans but also from a large variety of species. It also supports several other databases, such as EMBL, PIR and PDB.

\section{Navigation}

The site is relatively straightforward and there are introductory tutorials to help the novice learn how to use it. Search engines are provided, and these increase the probability of finding information about a specific gene or pathway. The data are also linked to other websites that can provide further information about the gene being analyzed. The site can be used freely by academic and non-academic users; nonacademic users cannot download data without a license agreement, however.

\section{Reporter's comments}

\section{Timeliness}


The site is updated daily and some of the information can be received on CD ROM, which is updated weekly.

\section{Best feature}

A huge amount of information from the genome project is collected and compared here. The pathway diagrams are particularly useful in understanding the exact action of a particular gene.

\section{Worst feature}

Although the site is well presented, it takes some time to get familiar with all the things it can offer.

\section{Related websites}

GeneCards provides a wide range of information on genes and their involvement in disease through searching with their approved gene symbol.

\section{Table of links}

Kyoto Encyclopedia of Genes and Genomes (KEGG)

GeneCards

\section{References}

1. Kyoto Encyclopedia of Genes and Genomes (KEGG). 